\title{
Paola CANOVA, Frontier Intimacies. Ayoreo Women and the Sexual Economy of the Paraguayan Chaco
}

\section{María Agustina Morando}

\section{OpenEdition}

\section{Journals}

Electronic version

URL: https://journals.openedition.org/jsa/19760

DOI: 10.4000/jsa. 19760

ISSN: 1957-7842

\section{Publisher}

Société des américanistes

\section{Printed version}

Date of publication: 30 September 2021

Number of pages: $277-279$

ISSN: 0037-9174

\section{Electronic reference}

María Agustina Morando, "Paola canova, Frontier Intimacies. Ayoreo Women and the Sexual Economy of the Paraguayan Chaco", Journal de la Société des américanistes [Online], 107-1 | 2021, Online since 30 September 2021, connection on 04 September 2022. URL: http://journals.openedition.org/jsa/19760 ; DOl: https://doi.org/10.4000/jsa.19760

This text was automatically generated on 4 September 2022

All rights reserved 


\title{
Paola CANOVA, Frontier Intimacies. Ayoreo Women and the Sexual Economy of the Paraguayan Chaco
}

\author{
María Agustina Morando
}

\section{REFERENCES}

Paola CANOVA, Frontier Intimacies. Ayoreo Women and the Sexual Economy of the Paraguayan Chaco, University of Texas Press, Austin, 2020, 208 p., bibliogr., index, photographs (black and white).

The Ayoreo are an indigenous group of the Gran Chaco established within the Northern Paraguayan and Southeastern Bolivian borders. The population living in Paraguayan territory (approximately 2,600 people) is divided into two main confederacies: the Direquene-gosode, or "people from the following day," and the Guidai-gosode, or "people from the villages." Until the 1960s, the Ayoreo remained uncontacted mainly due to the inaccessibility of their territory-often known in Guarani as Chaco ruguare, or "the tail of the Chaco," a term used to refer to the region as an isolated space. However, due to the rise of agro-industrial activity and the founding of diverse mission stations (Catholic, Mennonite, and Evangelical), the traditional way of life of this group has undergone accelerated and dramatic changes during recent decades.

In this book, Paola Canova focuses on a recent phenomenon that leads Ayoreo women to engage in monetized intimate liaisons with non-indigenous men, and is condensed in the vernacular term curajodie. This category was initially reported during the 1990s, when young women gradually started to engage in sexual relationships with outsiders. Based on the recording and analysis of a series of life histories of both indigenous and nonindigenous local peoples, Canova tracks the lives and practices of Ayoreo women and reconstructs the current commodification of their sexuality, which exposes the loopholes of this frontier capitalist system. 
The commodification of sexuality among Ayoreo women is linked both with rapid changes in the labor economy of the Chaco, which affect the ecological landscape and the natural resources available to indigenous communities, and with a historical pattern of discrimination against indigenous peoples. Money has become a constitutive factor of courting and marriage for younger indigenous women, leading to what the author calls a "commodification of intimacy." "Intimacy" thus becomes an analytical category that allows for an outright analysis of monetized liaisons beyond the mere sexual dimension. In fact, both the boundaries between indigenous and non-indigenous intimacies and their transgression highlight the multiple ways in which these relationships reproduce the logic of local economy and regimes of racial discrimination, in a labor system that constantly and deliberately expels indigenous people, and particularly women.

current circulation of money in the intimate sphere is a novel expression of customary practices of exchange and reciprocity that have been reconfigured to accommodate the expansion of a growing frontier economy. Indeed, in recent decades, money has been incorporated as a decisive element in the practice of Ayoreo intimacy and sexuality and as a sign of generosity re-signifying traditional courtship norms and values. In fact, during the courtship process, Ayoreo men traditionally used to offer the women they were interested in some necklaces or small gifts. As Canova explains, nowadays these gifts are progressively being replaced by others such as money or, in some cases, mobile phones. In this sense, money is incorporated into the circuit of intimacy without becoming a "moral" issue, and the Ayoreo girls do not describe the fact of receiving money in exchange for spending intimate time with a man in terms of a "commercial transaction."

5 This fact relates to the value of common respect for individual autonomy. As Canova insightfully describes, during puberty, any given girl's sexuality becomes a public matter openly discussed by family members, who provide advice about her expected behaviors. Even if during courtship a certain degree of autonomy is tolerated among Ayoreo women, there is also a social expectation that they will marry in the short term. After marriage, the independence to enjoy a free sexuality is restricted. Canova illustrates this by means of the metaphor of laughter: the laughter of a young woman symbolizes her freedom to choose a sexual partner, which is called inganare. However, when a woman marries, she no longer laughs, je ore cana. Traditionally, before marriage, a young woman may establish temporary relations with different men, referred to as ijnora or "friends." By contrast, men with whom stable relationships are maintained are called gajmai "boyfriend." The author therefore describes the money that these young women receive in exchange for these intimate encounters with outsider ijnora as "gift money," thus conceiving it as another element of traditional courtship. In fact, Ayoreo women see non-indigenous contexts as new horizons within which to explore sexuality while being single.

6 Although they are commodified, intimate relationships with non-indigenous men continue to be conceived in terms of exchange and reciprocity. This happens in a regional context in which the values of Christian and indigenous casuistry coexist, resulting in the disappearance of certain practices (e.g. infanticide) and the survival of others, albeit in other forms (e.g. courtship or multiple marriages). The clearest example of the latter is precisely the phenomenon of curajodie, whereby socially accepted values and behaviors of courtship and sexuality embody new practices that give meaning to intimacy in a context of increasing external pressures, which Canova describes as a 
"racialization of desire." Ayoreo girls thus condense and evoke non-indigenous perceptions about indigenous women, whose bodies are conceptualized as exotic and even abject, but also desired and sought by outsiders.

7 Young women, on the other hand, also begin to reshape their own aesthetic stereotypes based on female images found in popular media content: music videos, soap operas, and so on. Thus, Canova observes an increasing tendency among curajodie to consume Western clothes, make-up, and perfumes. In such a context, she also reports increasing levels of violence against indigenous women, including both physical and psychological aggression. In fact, the number of indigenous women murdered at the hands of nonindigenous men has increased in recent years and most of these cases remain unresolved. Canova argues that these kinds of relationships evade unambiguous categorization. This clearly poses a problem, because these practices are seen by non-indigenous people as a form of "sex work" that results in Ayoreo women being coerced into discontinuing that activity, both by Mennonites and by the Paraguayan state. By continuing with their activities, Ayoreo women challenge a discriminatory and exclusionary market system and deploy a parallel economy of intimacy in a highly masculinized sociocultural context.

8 The testimonies captured in this book describe in precious detail the multiple ways in which Ayoreo women signify and re-signify their sexual intimacy in a context of increasing pressures due to the growing advance of Western society. Indeed, the author succeeds in consistently tracing a close relationship between sociocultural, economic, and ecological transformations in the Chaco and the sexual practices of Ayoreo women. She succeeds as well in unveiling the complex mechanisms of intimacy exchange in a liminal space outside the boundaries of the national state, historically marked by a strong masculine influence. Therefore, this is undoubtedly an ethnography of great significance and impact, both for the field data collected and for the author's analysis, which allow us to explore one of the many ways in which indigenous modernities are constructed in a context of sharp economic and sociocultural change. Above all, Canova's book helps to place current indigenous women, with their practices, their experiences, and their discontents, on the center of the stage.

\section{AUTHORS}

MARÍA AGUSTINA MORANDO

IICS-CONICET/UCA (Argentina) 